\title{
К ВОПРОСУ О ПРИМЕНЕНИИ УГОЛОВНОЙ КОНФИСКАЦИИ
}

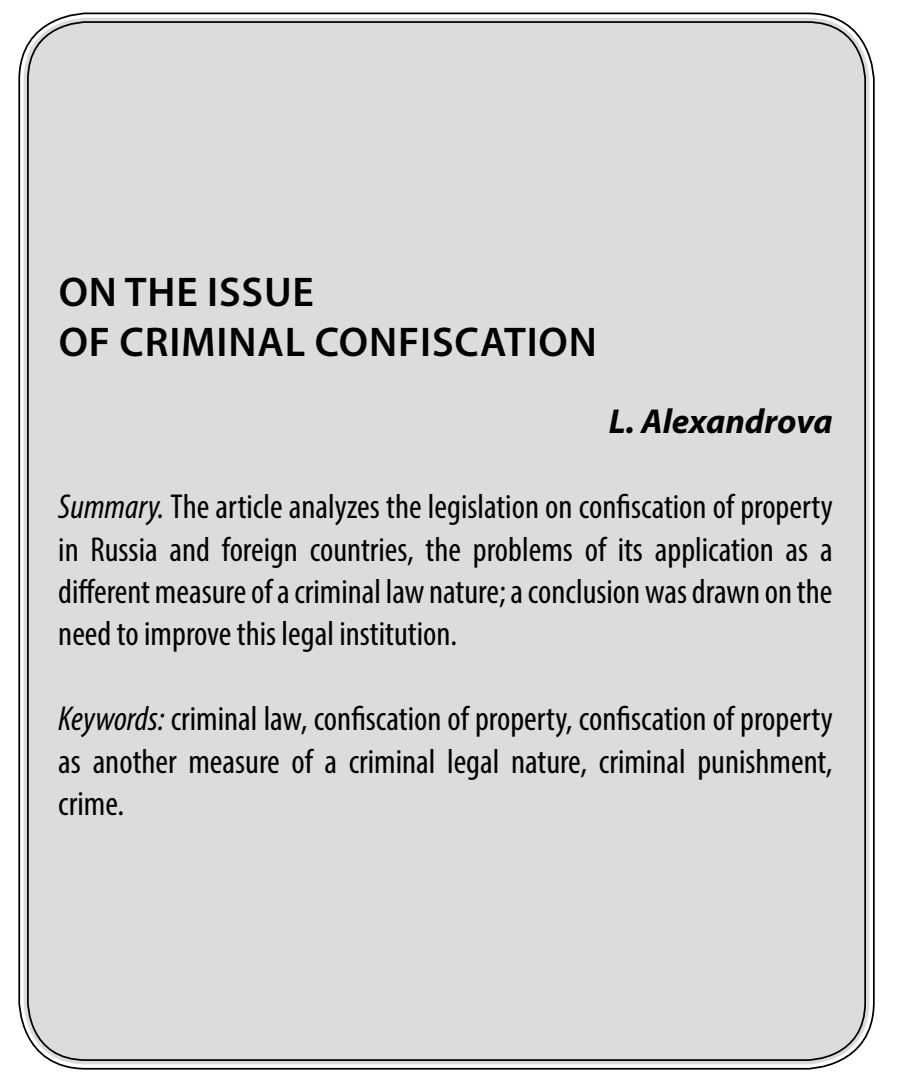

$\mathbf{K}$ онфискация имущество - принудительное изъятие материальных ценностей, определенных законом. Сам термин «конфискация имущества» происходит от латинского слова confiscatio, означающего в дословном переводе «отобрание в казну». В Большом юридическом словаре «конфискация имущества» определяется как принудительное безвозмездное изъятие в собственность государства всего или части имущества, являющегося собственностью лица, в качестве санкции за преступление либо за административное или гражданское правонарушение. [14]

Институт конфискации был известен еще в римском праве, в котором она была оформлена юридически как мера правового воздействия в виде имущественной ответственности виновного. Впоследствии конфискация стала распространяться в европейских государствах, в странах юго-восточной Азии, а также и в России. Конфискация имущества, как юридический акт, появилась во времена Киевской Руси. Так, в «Русской Правде» (своде законов при правлении Ярослава Мудрого) содержались нормы о конфискации имущества, которая применялась за поджог, казнокрадство, разбой и другие преступления. [2]

\section{Александрова Людмила Ивановна \\ С.н.с., Университет прокуратуры liud.alexandrova2012@yandex.ru}

Аннотация. В статье анализируется законодательства о конфискации имущества в России и зарубежных странах, проблемы ее применения как иной меры уголовно-правового характера; сделан вывод 0 необходимости совершенствования этого правового института.

Ключевые слова: уголовное право, конфискация имущества, конфискация имущества как иная мера уголовно-правового характера, уголовное наказание, преступление.

Понятие и содержание конфискация имущества трансформируется в зависимости от социально-экономических условий государства и это правовое явление является одним из наиболее спорным как в отечественном, так и в зарубежном законодательстве.

За время своего существования конфискация трижды исключалась из российского уголовного законодательства и трижды восстанавливалась, что вызывало раздражение общества и разделяло его на две непримиримые группы: сторонников и противников отмены конфискации имущества. Выступающие против исключения конфискации имущества, в том числе в качестве наказания, особенно жестко за это критиковали законодателя. [7]

В своем развитии конфискация имущества эволюционировала от дополнительного наказания до иной меры уголовно-правового характера. [1]

Конфискация имущества в настоящее время помещена в новый VI раздел Уголовного кодекса Российской Федерации (УК РФ) - «Иные мера уголовно правового характера», где она наряду с принудительными мерами 
медицинского характера», определена в качестве меры уголовно-правового характера.

«Новая» конфискация вызвала значительное количество вопросов и нареканий у ученых и практиков. Несмотря на то, что текст этой главы уже неоднократно подвергался редактированию, он по-прежнему вызывает определенные вопросы. Определение конфискации имущества в УК РФ содержится в ст. 104.1 («Конфискация имущества») и отличается от ранее действующих дефиниций этой меры. Действующим уголовным законодательством конфискация имущества определена как принудительное безвозмездное изъятие и обращение в собственность государства отдельного имущества осужденного (имущество, деньги и ценности, полученные в результате совершения преступных посягательств, и любых доходов от этого имущества, за исключением имущества и доходов от него, подлежащих возвращению законному владельцу; имущество, ценности и денежные активы, предназначенные для финансирования терроризма, экстремистской деятельности; орудие совершения преступления, принадлежащие обвиняемому и другое имущество, указанное в п «а» ч. 1 ст. 104.1 УК РФ) на основании обвинительного приговора (ст. 104.1 УК РФ «Конфискация имущества»).

Уголовная конфискация имущества в настоящее время может применяться по 74 преступлениям. В первоначальной редакции ст. 104.1 УК РФ предусматривалось только 45 конфискационных преступлений, т.е. за 14 лет существования новой конфискации количество преступлений, при совершении которых ее можно применять, увеличилось более на $60 \%$. Но для применения конфискации недостаточно «только статьи», необходимо дополнительно доказать еще, как минимум, один из следующих фактов: что имущество было добыто в результате совершения преступления; что это имущество было орудием или же средством для совершения преступления и что это имущество было приобретено на средства от преступной деятельности.

Логика предназначения конфискации имущества как иной меры уголовно-правового характера вызвало непонимание, как со стороны теоретиков уголовного права, так и практических работников, что подтверждается правоприменительной практикой.

Возвратив в УК РФ конфискацию имущества в новой форме, Россия привела свое законодательство в соответствие с требованием международного права, не закрепив при этом в законе основания, цели и порядок применения этой конфискации

Если ранее конфискация имущества являлась дополнительным видом уголовного наказания, то в действу- ющем уголовном законодательстве она не включена В перечень видов наказаний, установленных ст. 44 УК РФ («Виды наказания»), а также не стала дополнительным наказанием в соответствии со ст. 45 УК РФ («Основные и дополнительные виды наказаний»).

Следует отметить, что исключение конфискации как вида уголовного наказания противоречит ратифицированным Россией международным соглашениями, в том числе, Конвенция ООН против коррупции, принятой 31 октября 2003 г. Резолюцией 58/4 на 51-м пленарном заседании Генеральной Ассамблеи ООН; Конвенциям Совета Европы о конфискации и отмывании преступных доходов (1990 г.) и об уголовной ответственности за коррупцию (1999 г.); Конвенции ООН против транснациональной организованной преступности (2000 г.); Конвенции ООН о борьбе с финансированием терроризма (1999).

В законодательстве большинства стран конфискация имущества является дополнительной мерой, усиливающей роль основного уголовного наказания и широко применяется в уголовном законодательстве Франции, Швеции, Швейцарии, Голландии, Бельгии, Дании, Польши, Эстонской Республики, Латвийской Республики, Китайской Народной Республики и ряда других стран. При этом, наблюдается тенденция все более частого применения конфискации имущества, что лишний раз подтверждает ее немаловажную роль среди мер уголовно-правового характера и показывает устремление стран к достижению международно-правовых стандартов. [10]

Анализируемый вид уголовной конфискации имущества как иной меры уголовно-правового характера, применяемый российским законодательством, содержит некоторые формальные признаки ее в качестве наказания и, в частности, принудительный характер исполнения, наличие субъекта принуждения в лице государства, ограничение или лишение прав. Имеет место сходство в и целях применения конфискации как наказания, предусмотренного в ст. 43 УК РФ - восстановление социальной справедливости, общепредупредительное и частнопревентивное направление для исправления и перевоспитания виновного лица. Схожесть этих признаков дало основание некоторым ученым утверждать, что, по сути дела, конфискация, как иная мера уголовно-правового характера мало чем отличается от конфискации как наказания. [12] Вместе с тем, конфискация имущества, как иная мера уголовно-правового характера, лишена карательных функций и направлена, главным образом, на имущество преступника, совершившего преступления, приобретенного незаконно, конфискация которого является своего рода дополнительным способом разрешения уголовно-правового конфликта и возможного возмещения ущерба потерпевшему. [4] 
Наибольшей критике подвергается перечень составов преступлений, включенный в п. «а» ч. 1 ст. 104.1 УК РФ, при совершении которых допускается применение конфискации имущества. Данный перечень является закрытым и расширительному толкованию не подлежит

Упомянутые в ч. 1 ст. 104.1 УК РФ преступления, не содержат общего критерия и относятся к различным категориям преступлений. В перечне статей содержатся определенные преступления различной степени тяжести (от небольшой до особо тяжких), посягающих на различные объекты, имеющие корыстную и насильственную направленность. Единственным объединяющим признаком всех преступлений, указанных в названной статье УК РФ, является их умышленное совершение.

Деяния, при совершении которых возможна конфискация имущества, содержатся в 13 главах Особенной части УК РФ. Преступления против личности составляют около $16,6 \%$ от общего количества предусмотренных конфискационных преступлений; преступления в сфере экономики - 24\%; преступления против общественной безопасности и общественного порядка - 34,5\%; преступления против государственной власти - 22,6\%; преступления против мира и безопасности человечества $-2,3 \%$.

Вместе с тем, перечень не содержит «традиционные» корыстные экономические преступления, предусмотренные ст. 158 УК РФ («Кража»), ст. 159 УК РФ («Мошенничество») и все иные способы совершения мошеннических преступлений (ст. 159.1, 159.2, 159.3, 159.5, 159.6 УК РФ), ст. 160 УК РФ («Присвоение или растрата»), ст. 161 («Грабеж»), ст. 162 («Разбой») и др. Где, как не в мошенничестве, незаконном предпринимательстве, фиктивном банкротстве, искать деньги и ценности, нажитые преступным путем?

Нередко средства от совершения такого рода преступлений идут на поддержку экстремизма, терроризма, коррупцию и других преступлений, от совершения которых может защищать конфискация имущества.

Кроме того, при отсутствии в перечне статей ст. 104.1 УК РФ экономических преступлений крайне сложно решать вопросы, связанные с возвратом денежных средств, незаконно выведенных за рубеж и возмещением причиненного ущерба. В качестве примера можно привести дело в отношении бывшего первого вице-премьера Московской области А. Кузнецова, которому инкриминируются мошенничество, легализация денежных средств, полученных в результате совершения преступления, растрата. Сумма ущерба, причиненного бюджету Московской области в результате противоправных действий обвиняемого с участием его первого заместителя
В. Носова, осужденного ранее и отбывающего наказания в местах лишения свободы, составляет более 14 млрд. рублей, большая часть которых выведена за российскую границу и имеются большие сомнения, что их удастся вернуть в Россию. [13] Как было указано, ст. 159 УК РФ («Мошенничество») не включена в перечень составов преступлений, предусмотренных п. «а» ч. 1 ст. 104.1 УК РФ, за совершение которого возможно применение конфискации имущества.

Остаются также неразрешенными вопросы назначения конфискации имущества при вердикте присяжных о снисхождении, при назначении наказания ниже низшего предела, при неоконченном преступлении, условном осуждении, прекращении уголовного дела по не реабилитирующим основаниям и др.

Конфискация имущества - достаточно сильное средство в борьбе с преступностью, что доказывает, как предшествующая отечественная практика, так и зарубежное законодательство. Однако при реализации положений российского уголовного законодательства о применения конфискации имуществ некоторыми авторами отмечается, что данный институт не отвечает существующим потребностям правоприменения, криминогенной обстановки, не отвечает общепринятым принципам и нормам международного права. [9] О6ращая на это внимание, руководитель Следственного комитета Российской федерации А. Бастрыкин отметил, что «сегодня можно конфисковать, образно говоря, лишь то, с чем жулик попался. А другое наворованноенельзя. Поэтому из ста случаев конфискация применяется лишь в десяти». [3]

В этой связи научные и практические работники высказывают предложения о необходимости повышения карательной функции конфискации имущества и внесения изменений в законодательство положений, которые предусматривали бы возможность применения конфискации имущества в качестве дополнительного наказания в отношении лиц, осужденных за совершение экономических и коррупционных преступлений. Предлагается ограничить соответствующий перечень п. «а» ч. 1 ст. 104.1 УК РФ коррупционными и экономическими преступлениями, либо включить применение конфискации имущества в санкции конкретных статей Особенной части УК РФ по таким видам преступлений. [6]

Результативность применения конфискации имущества напрямую связана с умением правоохранительных органов незамедлительно установить наличие и местонахождение соответствующего имущества, а также доказать его связь с преступлением. Так, согласно с п. 8 ст. 73 УПК РФ подлежащими к до- 
казыванию относятся «обстоятельства, подтверждающие, что имущество, подлежащее конфискации в соответствии со статьей 104.1 Уголовного кодекса Российской Федерации, получено в результате совершения преступления или является доходами от этого имущества, либо использовалось или предназначалось для использования в качестве орудия, оборудования или иного средства совершения преступления либо для финансирования терроризма, экстремистской деятельности (экстремизма), организованной группы, незаконного вооруженного формирования, преступного сообщества (преступной организации)». Кроме того, в соответствии с положением п. 11 Постановления Пленума Верховного Суда Российской Федерации от 14.06.2018 № 17 «О некоторых вопросах, связанных с конфискацией имущества в уголовном судопроизводстве» (далее - Постановление № 17) в обвинительном приговоре должны быть указаны доказательства того, что имущество, подлежащее конфискации, получено в результате совершения преступления или являются доходами от этого имущества либо использовалось или предназначалось для применения его в качестве орудия, оборудования или иного средства преступления. Также обращено внимание на то, что для решения вопроса о конфискации имущества переданного обвиняемым другому лицу (организации), суду требуется на основе исследования доказательств установить, что лицо, у которого находится имущество, знало или должно было знать, что имущество получено в результате преступных действий или использовалось либо предназначалось для использования при совершении преступления (п. 7 Постановления № 17). Однако в ряде случаев подобные факты преступного происхождения имущества доказать достаточно сложно.

Согласно уголовному законодательству, бремя доказывания преступного характера происхождения имущества, находящегося в собственности у обвиняемого, возложено на обвинительную сторону. На практике задачи оперативно-розыскных подразделений по установлению имущества, подлежащего конфискации и сбору доказательств о его связи с преступлением решаются не в полном объеме. Так, только 14\% сотрудников различных оперативных подразделений МВД России, имеющих опыт практической службы в ОВД от 5 и более лет, участвовали в оперативно-розыскных мероприятиях, направленных на установление имущества, подлежащего конфискации. [6]

Объемы конфискованного имущества сравнительно незначительны по отношению к нанесенному ущербу. Нередко на момент рассмотрения дела обвиняемые практически уже не имеют ничего в своей собственности, поскольку имущество заблаговременно ими офи- циально было переоформлено на других лиц, что исключает на законных основаниях конфисковать такое имущество.

Правовой институт по возложению обязанности доказывания законности происхождения своего имущества и доходов на обвиняемого приобретает в настоящее время особую актуальность. По этому пути идут многие страны мира, например, США, Великобритания, Италия, Норвегия и др., применяя институт «in rem», предусматривающего конфискацию имущества, законность приобретения которого не может быть подтверждена его собственником. Возложение обязанности доказывания законности происхождения имущества на обвиняемого во многом поможет решать проблемы применения конфискации имущества, поскольку не будет необходимости сбора следственными органами соответствующих доказательств и возможно достаточным будет ограничиться сбором косвенных улик. К примеру, в Великобритании, в связи с тем, что правоохранительные органы на практике с большим трудом осуществляли сбор доказательств о преступном происхождении имущества, в 2017 году был принят Закон о криминальных финансах (Criminal Finances Act 2017), которым бремя доказывания легальности происхождения имущества и доходов перенесено на подозреваемых. При этом оперативные подразделения Великобритании в лице Агентства по розыску доходов вправе выходить в суд с ходатайством о вынесении приказа (resistant orders RO), запрещающем любому лицу распоряжаться собственностью, которая может подлежать реализации с целью последующей конфискации.[11]

Эффект принципа перевода бремени доказывания на собственника в отношении имущества подтверждается практикой многих государства. Эта процедура не подрывает принцип презумпции невиновности лица, она непосредственно обращена к имуществу, на незаконность происхождения которого свидетельствуют материалы дела. Институт «in rem» не противоречит презумпция невиновности и они являются взаимодополняющими. Принятие в России этого института позволит повысить эффективность борьбы с экономическими преступлениями, коррупцией, терроризмом и другими общественно опасными формами преступного поведения.

Очевидной является также проблема исполнения конфискации имущества. Если ранее порядок исполнения конфискации имущества был урегулирован ст. 62-67 Уголовно-исполнительного кодекса Российской Федерации (УИК РФ), то в настоящее время отсутствует законодательный акт, регламентирующий исполнение конфискации имущества. Следствием этого является факультативное принятие решения судьями о применении 
конфискации имущества, основанном исключительно на их субъективном усмотрении, а не на законных основаниях.

В настоящее время в ст. 2.2. УИК РФ устанавливаются общие положения и принципы исполнения наказаний, в том числе применения мер уголовно-правового характера. Однако в дальнейшем в УИК РФ не детализируются порядок исполнения ни конфискации имущества, ни принудительных мер медицинского характера, что требует законодательного урегулирования этих вопросов.

Подводя итог, следует признать, что рассматриваемый институт о конфискации имущества далек от совершенства и требует его дальнейшего совершенствования. Устранение отмеченных недостатков и противоречий позволит занять этому правовому институту достойное место в системе мер уголовно-правового воздействия, как действенное средство борьбы с преступностью.

\section{ЛИТЕРАТУРА}

1. Федеральный закон от 27.07.2006 № 153-Ф3 «0 внесении изменений в отдельные законодательные акты Российской Федерации в связи с принятием Федерального закона «0 ратификации конвенции совета Европы о предупреждении терроризма» и Федерального закона «0 противодействии терроризму».

2. Российское законодательство X-ХХ веков. В 9-ти томах. М. Юридическая литература. 1994. Т. 1.

3. Александрова И.А., Ионов В. А. «Проблемы совершенствования конфискации имущества в российском законодательстве» Вестник Нижегородской академии МВД России», 2011, № 1(14).

4. Бастрыкин А. И. Уголовное право России. Практический курс / под общ. ред. А. И. Бастрыкина, под науч. ред. А. В. Наумова; Р. А. Адельханян и др. 3-е изд., перераб. и доп. М.: Издательство «Волтерс Клувер», 2007. С. 808.

5. Волженкин Б. В. Загадки конфискации. Уголовное право: стратегия развития в 21 веке: Материалы 4-й Международной научно-практической конференции. М., 2007.

6. Мартыненко Э. В. Конфискация имущества в действующем российском уголовном праве: монография. М.Ю, 2011. С. 4.

7. Мартыненко Э. В. Положения о конфискации имущества, содержащиеся в Уголовном кодексе РФ, нуждающиеся в совершенствовании // Известия Тульского государственного университета. Экономические и юридические науки. 2013 № 2-3. С. 151-155.

8. Назаренко Г. В. Конфискация имущества как иная мера уголовно-правового характера: Противодействие преступности: уголовно-правовые, криминологические и уголовно-исполнительные аспекты: Материалы III Российского конгресса уголовного права. М., 2008. С. 84.

9. Никитина А.В., Бурма 0. А. Проблемы имплементации норм международного права в сфере борьбы с коррупцией в российском законодательстве. Молодой ученый. 2018. № 6. С. 133-136. URL https://moluch.ru/archive/192/48201/.

10. Самойлова С. Ю. Конфискация имущества в современном уголовном законодательстве зарубежных стран// Вестник Южно-Уральского государственного университета. № 40. 209. С. 62-66.

11. Тугаринов Н.В. «Зарубежный опыт по вопросам совершенствования установления имущества, подлежащего конфискации». Научный журнал «оauт» № 15, 20.09.2018.

12. Чучаев А. А. Конфискация возвращена в Уголовный кодекс, но в другом качестве. Законность. 2006. № 9. С. 12-13.

13. Информация Следственного комитета Российской Федерации URL: https://sledcom.ru/news/item/1373085/?print

14. Большой юридический словарь URL: https://gufo.me/dict/law 